\title{
Temporomandibuláris ízületi és vertikális ortodonciai rendellenességek előfordulási gyakorisága, valamint azok összefüggései nagyszámú populáció szúrővizsgálata alapján
}

\author{
DR. MADLÉNA MELINDA*, DR. FEJÉRDY PÁL**, IFJ. DR KAÁN MIKLÓS* ${ }^{*}$ DR. HERMANN PÉTER*
}

\begin{abstract}
Felmérésünkben 4606 önkéntes személy (2923 nő, 1683 férfi) vett részt. A TM ízület kóros működésére jellemző panaszokat, tüneteket anamnézis és fizikális vizsgálat segítségével írtuk le, korcsoportok, nemek és régiók szerint értékeltük. Az ortodonciai eltérések közül a mélyharapást, valamint a nyitottharapást regisztráltuk. A TM ízület kóros múködésére utaló tünet közel 41 százalékban fordult elö, leggyakrabban a 35-44 éveseknél. A ízület kattanásának, vagy krepitációjának gyakorisága szignifikánsan nagyobb volt nőknél, mint férfiaknál. A legtöbb ízületi elváltozásra utaló tünet a Dél-Dunántúlon, a legkevesebb a Közép-Dunántúlon volt tapasztalható, közöttük a deviáció/deflexió gyakoriságában szignifikáns különbség mutatkozott. A mélyharapás a 35-44 éveseknél volt leggyakrabban regisztrálható, férfiaknál magasabb arányban, mint a nőknél. A legfiatalabb és a két legidősebb korcsoportot kivéve szignifikáns összefüggést tapasztaltunk a mélyharapás és az ízületi fájdalom, valamint a mélyharapás és az ízületi hangjelenség előfordulása között. Mélyharapás a Dél-Dunántúlon, nyitottharapás a Dél-Alföldön fordult elő leggyakrabban. Konklúzió: célzott egészségügyi programok szükségesek a meglevő állapotok javítására.
\end{abstract}

Kulcsszavak: epidemiológia, temporomandibuláris ízület, mélyharapás, nyitottharapás

A temporomandibuláris (TM) ízület kóros elváltozásai bármely életkorban előfordulhatnak. A klinikai tünetek nemenként nem mutatnak eltérést, előfordulási gyakoriságuk azonban a korábbi vizsgálatok szerint hétszer nagyobb nőknél, mint férfiaknál, bár ezek nem mindig járnak objektív, kimutatható ízületi elváltozásokkal [8]. A TM ízületre irányuló epidemiológiai vizsgálatok módszerei nagyon különbözőek lehetnek (korcsoportok, vizsgálati módszerek, feldolgozás szempontjai stb.), ezért legtöbbször nem, vagy csak nehezen hasonlíthatók össze.

A TM ízület elváltozásainak etiológiája multifaktoriális, számos tényező által befolyásolt. A legfontosabbak ezek közül az anatómiai rendellenességek, az okklúzális anomáliák, a foghiánnyal, pszichológiai vagy szisztémás megbetegedésekkel (pl. rheumatoid arthritis) kapcsolatos tényezők, de befolyásoló faktorként szerepelhetnek a traumák, a parafunkciók, viselkedési, szociális, emocionális és pszichés tényezők [3, 8, 17, 39]. A TMI elváltozások kialakulása összefügghet az instabil okklúzióval, a fogazati státusszal (a foghiányok és a pótoltság jellegzetességeivel), az ortodonciai anomáliákkal, illetve ortodonciai vagy ortognát sebészeti beavatkozásokkal is [1, 30, 34, 35].

A TM ízületi elváltozások leggyakoribb klinikai tünetei közé tartoznak az orofaciális fájdalom, az ízületi hangjelenség, a mandibula korlátozott mozgása, nyo- másérzékenység az ízületben és az ezzel összefüggő izmokban, a mandibula deviációja vagy deflexiója szájnyitáskor. A TM ízület elváltozásai okozhatnak rágási nehézséget, fejfájást is. A TM ízület kóros müködésére utaló tünetek a populáció átlagosan 20-75\%-ában kimutathatók, kezelésükre azonban ezen pácienseknek csupán 2-4\%-a jelenik meg orvosnál [8]. A TM ízület megbetegedéseit, az ennek következtében kialakuló tünetek hazai előfordulását felnőttek körében, 55 év feletti korcsoportban Heinrich és munkatársai (1995), 15-65 éveseknél Ember (1986), illetve Ember és munkatársai (1987), 18 és 31 év közötti fogorvostan-hallgatókon pedig Szentpétery és munkatársai (1986) vizsgálták [10, 12, 18, 36].

Jelen munkánkban célunk az volt, hogy meghatározzuk a TM ízület betegségeivel kapcsolatos kóros tünetek és a vertikális ortodonciai rendellenességek előfordulási gyakoriságát, valamint ezek összefüggéseit a hazai felnőtt populációban, nagyszámú populáció vizsgálata alapján.

\section{Anyag és módszer}

A Semmelweis Egyetem Fogpótlástani Klinikája 20032004-ben epidemiológiai felmérést szervezett a hazai felnőtt lakosság körében. A felmérésben a Röntgenernyő és Fényképszűrő Állomások által végzett tüdőszü- 


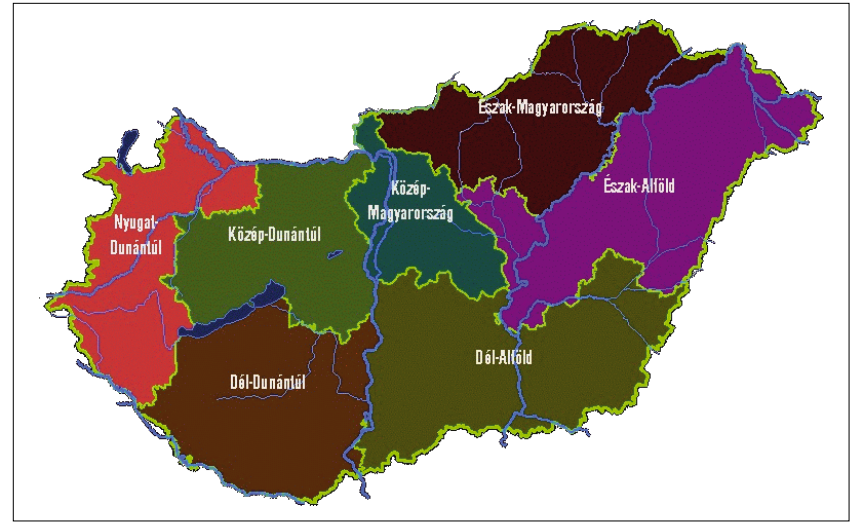

1. ábra: Statisztikai régiók megoszlása Magyarországon

résekhez kapcsolódóan 4606, beleegyező nyilatkozatot tevő, önkéntes személy (2923 nő és 1683 férfi) vett részt, átlag életkoruk $46,37 \pm 7,89$ év (férfiak: 44,41 \pm 17,14; nők: $48,09 \pm 18,36$ év) volt. A vizsgált populációt korcsoportokra osztva értékeltük, ezek a következők: 19 évesek, illetve ennél fiatalabb nagykorúak, 20-24 évesek, 25-34 évesek, 35-44 évesek, 45-64 évesek, 6574 évesek és 75 évesek vagy ennél idősebbek. A vizsgálati helyszínek a reprezentativitás érdekében felölelték az ország összes régióját (1. ábra), a fővárost, a nagyvárosok lakosságát és a vonzáskörzetükben élő lakosságot egyaránt. A vizsgálatok során kapott információkat az erre a célra készített számítógépes program segítségével a helyszínen rögzítettük. A vizsgálati helyszínek sokfélesége - főváros, nagyvárosok, kistelepülések - miatt az adatok bizonyos demográfiai-topográfiai aránytalanságot mutattak volna, ezért úgynevezett „súlyozás”-sal kerültek meghatározásra [6], így a feldolgozott információkat a régiókban lakók számarányainak megfelelően tudtuk figyelembe venni. A felmérés során a TM ízület jellemzőin kívül rögzítettük a kariológiai és parodontológiai státuszt, a táplálkozási

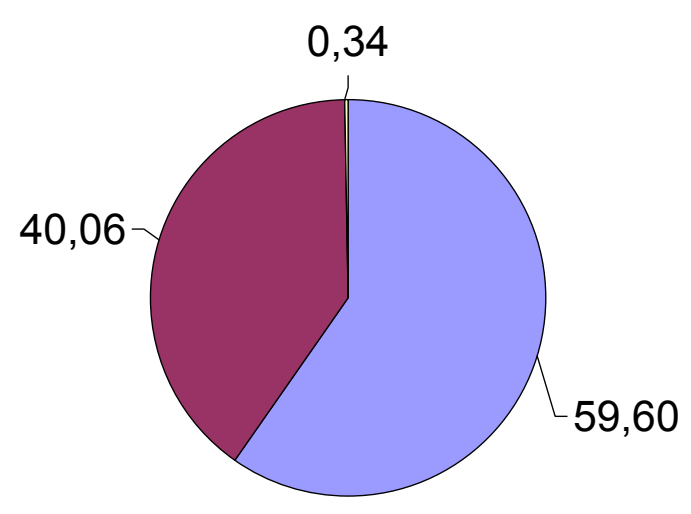

$\square$ Tünetek nélküli egyének

$\square$ Tüneteket mutató egyének

$\square A$ vizsgálat ezen részéböl kizárt egyének

2. ábra: A TM ízület elváltozására utaló tünetek gyakorisága felnőtt korú populációban (\%) és szájhigiénés szokásokat, a szájnyálkahártya elváltozásokat és a protetikai jellemzőket is. Ezeket az információkat más helyeken már közöltük [14, 15, 20, 21, 27-29, 38].

A TM ízület kóros müködésére jellemző tüneteket az anamnézis és fizikális vizsgálat segítségével írtuk le. A következő tüneteket értékeltük: fájdalom, ízületi hangjelenség, nyomásérzékenység, a mandibula korlátozott mozgása valamint deviációja (WHO, 1997) [43]. A tüneteket két csoportra osztva, a következők szerint regisztráltuk:

Szubjektív tünetek: fájdalom (jobb oldali ízületben, bal oldali ízületben); nyomásérzékenység (jobb oldali ízületben, bal oldali ízületben)

Objektív tünetek: ízületi hangjelenség (kattanás, krepitáció) (jobb oldali, bal oldali ízületben); deviáció / deflexió (2 mm felett); korlátozott mozgás [mérése: megtartott fogazatnál a középső felső metszőfog és az alsó metszőfogak incizális élei közötti távolság (nőknél: < $35 \mathrm{~mm}$, férfiaknál < $40 \mathrm{~mm}$ szájnyitás nyithatóság csökkentnek mondható), teljes fogatlanság esetén a gerincél-vonalak középső pontjai közötti távolság [(felnőttnél csökkentnek mondható, ha $<50 \mathrm{~mm}$ ); részleges fogatlanság esetén a metszőfog éle és a gerincél-vonal középső pontja közötti távolság (nőknél: $<40 \mathrm{~mm}$, férfiaknál < $45 \mathrm{~mm}$ szájnyitás nyithatóság csökkentnek mondható; oldalmozgás, propulzió esetén $<8 \mathrm{~mm}$ a mozgás korlátozottnak tekinthető)].

Az ortodonciai eltérések vizsgálatakor a vertikális eltéréseket, a mélyharapás (a felső metszőfogak $2 \mathrm{~mm}$-nél nagyobb mértékben fedik az alsó metszőfogak koronáját), valamint a nyitottharapás (az alsó és felső fogív fogai az elülső vagy oldalsó régióban nem érintkeznek egymással) előfordulását regisztráltuk.

A vizsgálatok előtt a vizsgálatot végzőknél a kalibráció a WHO (1997) ajánlása szerint történt [43].

Az adatok feldolgozása SPSS for Windows 13.0 programcsomaggal, leíró statisztikai módszerek és T próba alkalmazásával történt. Az eredmények számszerü megjelölésekor a súlyozott értékek kerülnek közlésre.

\section{Eredmények}

A megvizsgáltak közel 41 százalékában fordult elő a TM ízület kóros müködésére utaló tünet (2. ábra). A tünetek gyakoriságának vonatkozásában legtöbbször a mandibula deviációja vagy deflexiója (az összes tünettel rendelkező résztvevő $52,42 \%$-a) és az ízületi hangjelenség (az összes tünettel rendelkező résztvevő 43,74\%-a) volt kimutatható (3. ábra). Az elváltozást mutató vizsgálati alanyok 67,26 százaléka rendelkezett egy tünettel (többségüknél ez az ízületi hangjelenség volt), 31,38 százalékuk egyszerre kettővel, és csupán 1,25 százalékuknál jelentkezett három, 0,05-0,05 százalékuknál négy, illetve öt regisztrált tünet egyidejüleg.

$A z$ életkor szerinti értékeléskor szűrővizsgálatunkban a 35-44 éves korosztály körében fordult elő a leg- 


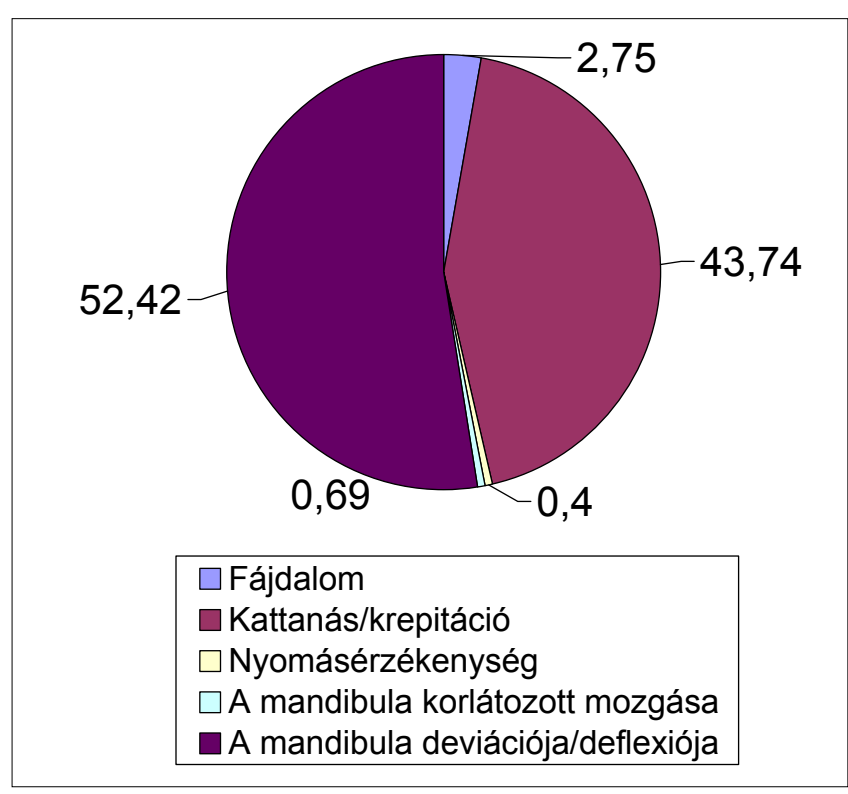

3. ábra: TM ízületi tünetek előfordulási gyakoriságának százalékos megoszlása

a betegség által érintett felnőtt korú populációban

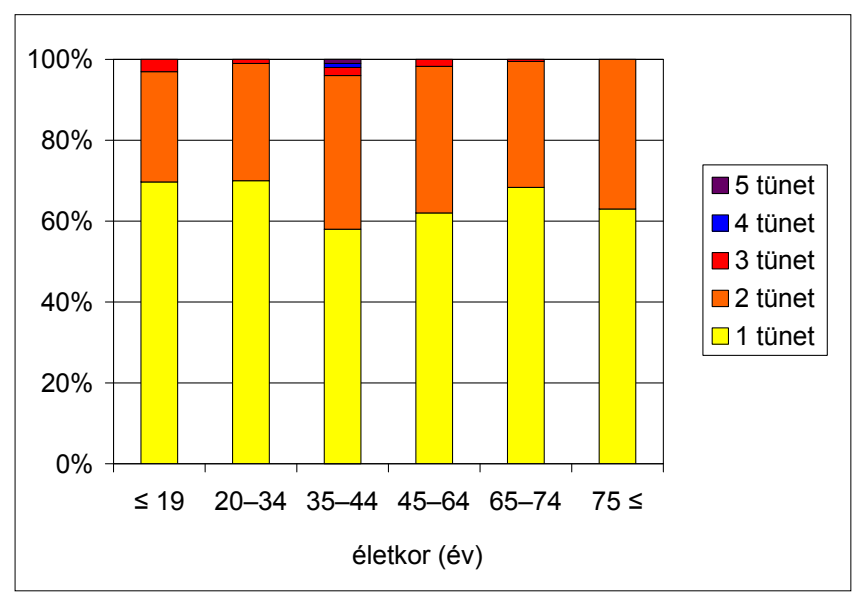

4. ábra: A TM ízületi tünet százalékos előfordulása életkor szerinti csoportosításban

a betegség által érintett felnőtt korú populációban

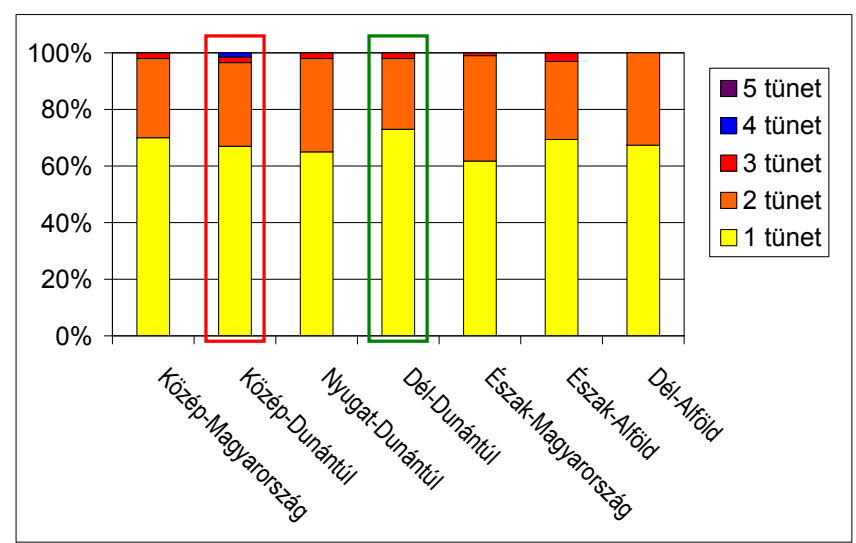

5. ábra: A TM ízületi tünetek százalékos előfordulása régiónként, a betegség által érintett felnőtt korú populációban

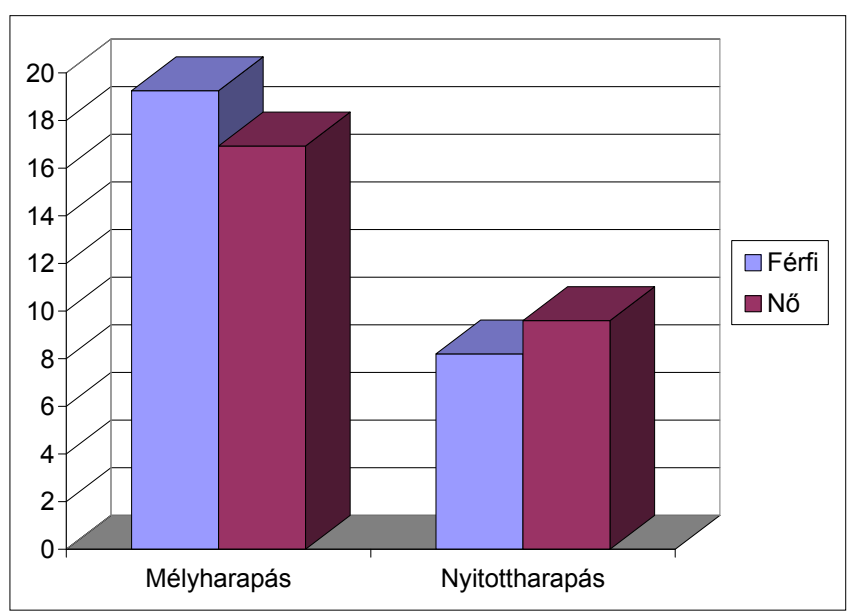

6. ábra: Vertikális ortodonciai eltérések előfordulása nemenként, felnőtt korú populációban (\%)

gyakrabban a TM ízület kóros működésére utaló tünet $(45,19 \%)$, ami többnyire a mandibula deviációja / deflexiója, vagy az ízület kattanása / krepitációja (az előbbiek 31,15\%, az utóbbiak 27,14\%) volt. Ugyancsak ebben a korosztályban panaszkodtak legmagasabb számban a betegek egyszerre több tünetről (4. ábra).

A nemek szerint megvizsgálva, a TM ízület elváltozásra utaló kóros tünetek közül mindegyik nőknél fordult elő nagyobb gyakorisággal. TM ízület kattanásának, vagy krepitációjának gyakorisága szignifikánsan nagyobb volt nőknél $(27,19 \%)$, mint férfiaknál: $(14,64 \%)$ $(p<0,05)$, a többi tünet gyakoriságában a különbség nem volt szignifikáns $(p>0,05)$.

A régiók vonatkozásában a dél-dunántúli régióban fordult elő a leggyakrabban a TM ízület elváltozására utaló tünet $(44,70 \%)$, ami leginkább $(42,42 \%)$ állcsúcs deviáció / deflexió volt, ízületi hangjelenség 27,27\%ban volt regisztrálható. A két említett tünet együttesen $31 \%$-ban fordult elő. A legkevesebb elváltozás a középdunántúli régióban volt tapasztalható, itt a deviáció / deflexió 19,27\%-ban, hangjelenség pedig 21,07\%-ban, a két tünet együtt 20,0\%-ban fordult elő. A két régió között a deviáció / deflexió gyakoriságának vonatkozásában szignifikáns különbség mutatkozott $(p<0,05)$.

A dél-dunántúli régióban (tehát ahol a legtöbb elváltozás lett feljegyezve) mutatkozott a legtöbb egy tünettel jelentkező beteg, míg a kevés elváltozást mutató közép-dunántúli régióban magasabb a több tünettel rendelkezők száma (5. ábra).

A vizsgált populációban a vertikális eltérések közül a mélyharapás a férfiaknál magasabb arányban fordult elő, mint a nőknél, de a nemek közötti eltérés ebben a tekintetben nem volt szignifikáns $(p>0,05)(6$. ábra). A legfiatalabb és a két legidősebb korcsoportot kivéve a teljes populációban szignifikáns összefüggést lehetett kimutatni a mélyharapás és az ízületi fájdalom, valamint a mélyharapás és az ízületi hangjelenség előfordulása között $(p<0,05)$. Az életkorok tekintetében a mélyharapás a 35-44 éveseknél volt leggyakrabban 


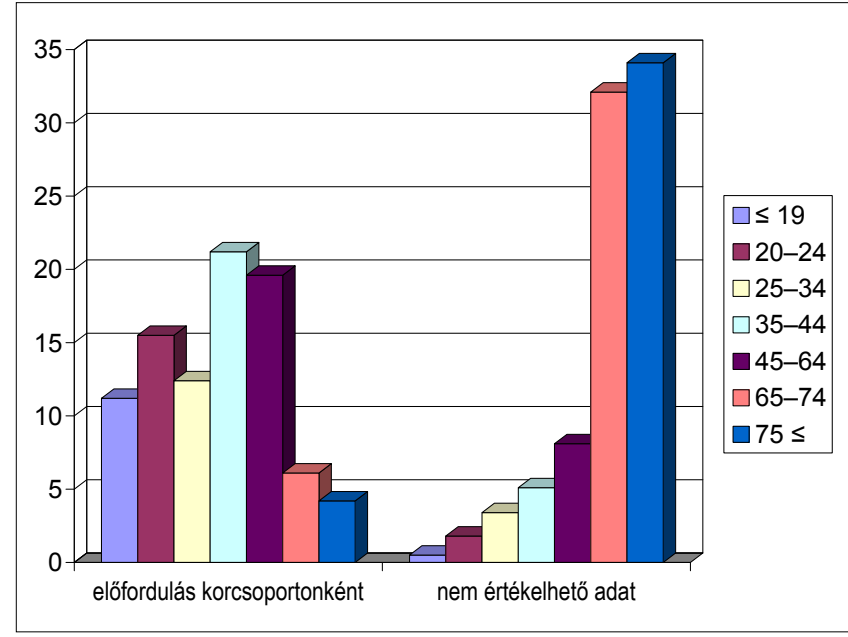

7. ábra: A mélyharapás előfordulása korcsoportonként (\%)

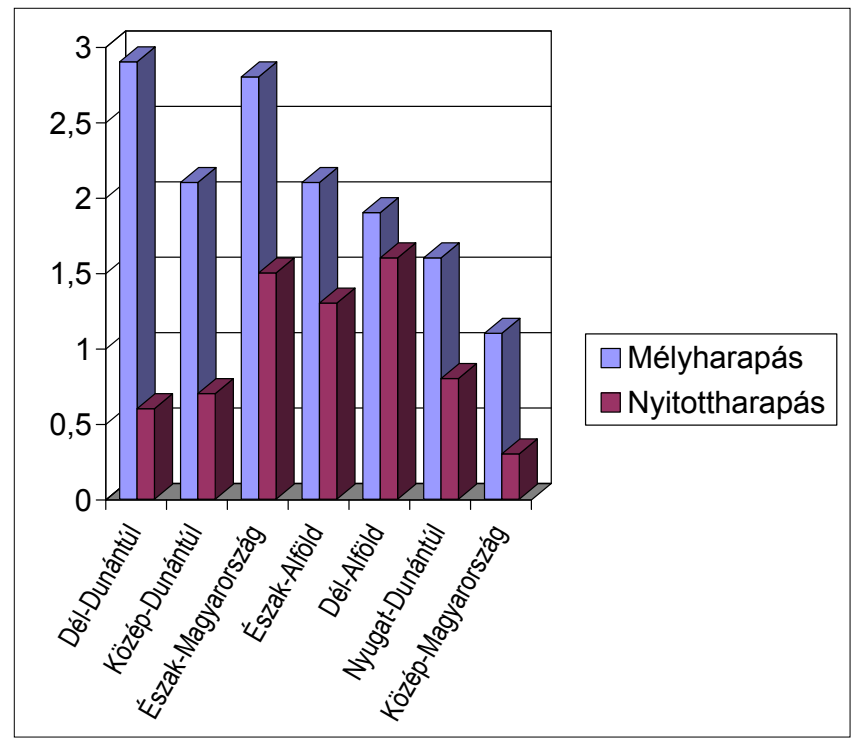

8. ábra: A mélyharapás és nyitottharapás előfordulása régiónként (\%)

regisztrálható (7. ábra). Régiók vonatkozásában mélyharapás a dél-dunántúli régióban, nyitottharapás a Dél Alföldön fordult elő leggyakrabban (8. ábra).

\section{Megbeszélés}

A hazai felnőttkorú populáció szájegészségi állapotával kapcsolatos reprezentatív szürővizsgálat kariológiai, parodontológiai, bizonyos fogpótlástani jellemzői, szájnyálkahártya-elváltozások gyakoriságára, táplálkozási és szájhigiénés szokásokra vonatkozó eredményei korábbi közleményekben ismertetésre kerültek [14, 15, 20, 21, 27-29, 38]. Jelen közleményben a TM ízület kóros működésére utaló tünetek és a vertikális ortodonciai rendellenességek gyakoriságát, illetve ezek összefüggéseit foglaljuk össze.

Heinrich és munkatársai (1995) Győrben és környé- kén 55 év feletti populációban klinikailag vizsgálták a rágóapparátus működését [18]. Tapasztalataik szerint a TM ízület elváltozása 90\%-ban nem regisztrálható, 55-64 éveseknél 6,4\%, 65-74 éveseknél 6,2\%; 74 éven felülieknél 9,5\%-ban fordul elő ízületi hangjelenség, mely a leggyakoribb szimptóma. Fájdalom 0,4\%-ban volt regisztrálható ebben a vizsgálatban.

Ember 1986-ban 15-65 éveseken végzett TM ízületi vizsgálatokat. Eredményei azt mutatják, hogy a vizsgált populáció $68 \%$-ban panaszmentes volt. Ugyanakkor a klinikai funkciós analízis eredményeként 91,7\%-ban objektíven észlelték a TM ízületi diszfunkciós szindróma tüneteit [10]. Ezekben a vizsgálatokban a nemek között nem volt különbség, bár Ember és Szabados (1985) korábbi vizsgálatai szerint diszfunkció gyanújával beküldött nőbetegeken $3 \times$ nagyobb gyakorisággal észlelhető diszfunkció kórképe [11]. Mundt és munkatársai (2005) 35-74 évesek vizsgálatakor értékelték a nemek között tapasztalható különbségeket: nőknél nem tapasztaltak szignifikáns összefüggést az okkluzális jellemzők (foghiányok) és a TM ízületi diszfunkció jelei között [31]. Szentpétery és munkatársai (1986) 18 és 31 év közötti fogorvostan-hallgatók vizsgálatakor szintén nem találtak különbséget a TM ízületi diszfunkció előfordulásában a nemek között. Anamnesztikusan a vizsgált személyek többsége panaszmentes volt, ugyanakkor klinikai vizsgálattal csupán 2-3 százalékuknál nem találtak objektív tüneteket [36]. Jelen felmérésünkben az objektív tünetek (ízületi hangjelenség, deviáció / deflexió, korlátozott mozgás) előfordulása lényegesen magasabb volt a teljes populációra vonatkoztatva és a kóros tünetek mindegyike nőknél fordult elő gyakrabban.

Ember és munkatársai (1987) 15-65 évesek vizsgálatakor a TM ízületi diszfunkció tüneteinek előfordulásában azt tapasztalták, hogy 20-40 éveseknél a tünetek nagyobb gyakorisággal fordulnak elő, mint a többi korcsoportokban [12]. Jelen vizsgálataink szerint a 3544 éves korosztály érintett leginkább a kóros ízületi tünetek előfordulásában, ami arra utal, hogy az elmúlt csaknem két évtizedben (a vizsgálatokat 2003-2004ben végeztük) a tünetek magasabb előfordulási aránya az életkor vonatkozásában kissé eltolódott.

Jelen vizsgálatainkban megfigyelhető, hogy kevesebb TM ízületi elváltozás mutatkozott a fiatalabb és az idősebb korcsoportoknál, akiknél többnyire még mérsékelten hiányos (esetleg hiánytalan) a fogazat [27, 29], illetve akiknél már nem nagy valószínűséggel készíthető kizárólag rögzített fogpótlás. A legtöbb tünet a 3544 éveseknél jelentkezett, akik föleg rögzített fogpótlást viseltek, illetve mérsékelten hiányos fogazatuk volt, ezért föleg rögzített fogpótlást viseltek. Ez az okklúziós egységek nem megfelelő működésére vezethető viszsza, aminek fő okai lehetnek: az ellátatlan foghiány, illetve a rögzített fogpótlások nagyobb aránya és/vagy az okklúziós felszínek nem megfelelő kialakítása [13]. A rögzített fogpótlások rágófelszínének anyaga többnyire fém vagy kerámia, amelynek helyes vagy helytelen kialakítása befolyással van az ízület működésére. 
A részleges lemezes fogpótlások megjelenésével ismét csökken a TM ízületi elváltozások előfordulása; mivel ilyenkor a rágófelszín (a lemezes fogpótlás révén) részben akrilát - ez az egyéni rágópályáknak megfelelően „bekophat”, így kevésbé terhelődik a TM ízület.

A foghiány mértéke a kor előrehaladtával növekedést mutat $[18,27,29]$. A foghiány okozta traumás okklúzió a fogak számának csökkenésével az ízület relatíve csökkent terhelését eredményezheti, így az idősebb korosztályban - ahol gyakoribb a nagymértékű vagy teljes fogatlanság - kevesebb elváltozás regisztrálható.

Vizsgálati eredményeink megegyeznek List és Dworkin (1996) megállapításaival, miszerint a TM ízület okozta fájdalom gyakoribb nőknél, mint férfiaknál, és főleg 30-40 éves kor körül jellemző [24]. A nemenkénti megoszlás vonatkozásában jelen vizsgálatainkban is a nők esetében tapasztalható nagyobb százalékban TM ízületi elváltozásra utaló tünet, ami - az előzőek értelmében - feltehetőleg a magasabb számban előforduló rögzített fogpótlásokkal hozható összefüggésbe [13].

A TM ízület megbetegedések multifaktoriálisak, de alapvetően pszichológiai tényezőkkel (elsősorban a depresszióval és a szomatizációval) hozhatók összefüggésbe. Vágó (1989 a, b, c) szerint a TM ízületi diszfunkció kialakulásában a parafunkciós és pszichés tényezők a szignifikáns etiológiai faktorok, amelyeket a hibás okklúzió és az általános egészségi állapot döntően befolyásol [40-42]. Slade és munkatársai (2007) szintén a pszichológiai faktorok jelentős szerepét hangsúlyozzák, Ember és Szabados (1985) megállapításaihoz hasonlóan [11, 35]. Ember (1976), valamint Ember és munkatársai (1987) összefüggést találtak a diszfunkció foka, a maradófogak számának csökkenése, az okklúziós zavar, a parafunkció és a bruxizmus között [9, 12]. Carlsson és munkatársai (2002), valamint Pergamallan és munkatársai (2003) a bruxizmust és egyéb orális parafunkciókat szintén veszélyeztető faktorként írták le a TM ízületi panaszok kialakulásában, sőt a parafunkciók száma és a TM ízületi panaszok súlyossága között is szignifikáns összefüggést írtak le [4, 32]. Az okklúziós eltérések és a TM ízület kóros müködése közötti összefüggések vizsgálatakor Selaimen és munkatársai (2007) szerint a szemfogvezetés hiánya, illetve a disztálharapás jelentős szerepet játszik a TM ízülettel kapcsolatos kóros tünetek kialakulásában [34]. A harapási eltéréseket korábban hazánkban Szilágyi és munkatársai (1997), Czukor (1994), Gábris és munkatársai (2006) vizsgálták fiatalabb, illetve nem reprezentatív betegcsoportokban [5, 16, 37]. A TM ízületi tünetekkel párhuzamosan csupán Szilágyi és munkatársai (1997) végeztek vizsgálatokat az ortodonciai eltérések előfordulását illetően Turner-szindrómás betegcsoportban, az összefüggések vizsgálata nélkül. Drangsholt és LeResche (1999) szerint az ortodonciai eltérések inkább csak veszélyeztető faktorként szerepelnek [7]. Az ortodonciai anomáliák és a TM ízületi panaszok összefüggésével kapcsolatban a vizsgálatok többsége keresztmetszeti volt, amelyekben a szerzők arra a következtetésre jutottak, hogy az extrém esetektől eltekintve nincs szignifikáns összefüggés a malokklúzió és a TM ízületi panaszok között [22, 30]. Az eltérések közül - mértékétől függően - a mélyharapás játszhat jelentősebb szerepet a TM ízületi panaszok kialakulásában. A mélyharapás és az ízületi panaszok közötti összefüggést számos szerző vizsgálta [19, 23, 26, 33]. A nagyfokú mélyharapás a rágóapparátuson keresztül fejtheti ki hatását, ha az adaptációs képességet meghaladja. Mivel az adaptációs képesség egyénenként is változó, az elváltozás hatása is különböző $[2,25]$. Jelen vizsgálatunkban, ellentétben a korábbi vizsgálatok megállapításaival, szignifikáns összefüggés mutatkozott az ízületi fájdalom, valamint az ízületi hangjelenség és a mélyharapás között. A mélyharapás elöfordulása leggyakoribbnak a dél-dunántúli régióban mutatkozott, ahol a legtöbb ízületi elváltozást lehetett regisztrálni. Bár ugyanebben a régióban mutatkozott a legtöbb egy tünettel rendelkező egyén, a leírtak alapján úgy tünik, ez a régió bizonyos összefüggések vonatkozásaiban rosszabb képet mutat a többinél. A TM ízület kóros elváltozásaival összefüggést mutató mélyharapás a 3544 éves korcsoportban magas előfordulást mutatott, ami az említett mélyharapás és ízületi tünetek közötti összefüggést is alátámasztja, mivel ebben a korcsoportban volt kimutatható a legtöbb ízületi tünet. Ugyanakkor - feltehetőleg a fogpótlás, illetve a fogpótlás hiánya miatt - a nem értékelhető adatok száma a korral növekszik. Az említett összefüggéseken kívül közleményünk rámutat a pszichoszociális vonatkozások TM ízületi problémákkal kapcsolatos jelentőségére is, mely különösen a középkorú nők esetében lehet figyelemre méltó.

Vizsgálataink eredményei alapján elmondható, hogy olyan célzott programok tervezésére van szükség, melyek mind a fogpótlások mennyiségi és minőségi javulását, mind az időben és megfelelő módon végzett fogszabályozó kezelések, valamint a pszichológiai vonatkozások jelentőségét hangsúlyozva, a meglevő állapotokat jelentősen javíthatják. Vizsgálati eredményeink ugyanakkor későbbi összehasonlítások alapjául is szolgálhatnak a lakosság TM ízületi elváltozásokkal potenciálisan összefüggő egészségi állapotának longitudinális értékeléséhez.

\section{Irodalom}

1. Abrahamsson C, Ekberg EC, Henrikson T, Bondemark L: Alterations of temporomandibular disorders before and after orthognatic surgery. Angle Orthod 2007, 77: 729-734.

2. Anders C, Harzer W, Eckgard L: Axiographic evaluation of mandibular mobility in children with Angle Class II/2 malocclusion (deep overbite). J Orofac Orthop 2000, 61: 45-53.

3. Angyal J, Keszthelyı G: A temporomandibuláris ízület érintettsége rheumatoid arthritis esetén. Fogorv Szle 2001, 94: 151-155.

4. Carlsson Ge, Egermark I, Magnusson T: Predictors of signs and symptomes of temporomandibular disorders: A 20 year follow up study from childhood to adulthood. Acta Odontol Scand 2002, 60: 180-185. 
5. CzUkoR J: WHO epidemiológiai vizsgálatok Magyarország 1985ben és 1991-ben. Fogorv Szle 1994, 87: 223-235.

6. DINYA E: Biometria az orvosi gyakorlatban. Medicina, Budapest, 2001, 171-204.

7. Drangsholt M, LE Reshce L:Temporomandibular disorder pain In Epidemiology of pain. Crombie IK, Croft PR, Linton SJ, LeResche L, von Korff M (szerk.) Seattle, ISP PRESS 17-18.

8. Durham J: Temporomandibular disorders (TMD): an overview. Oral Surg 2008, 1: 60-68.

9. Ember E: A parafunkció káros következményei. Fogorv Szle 1976, 69: $167-171$.

10. EMBER E: A TMI diszfunkciós szindróma epidemiológiai vizsgálata Fogorv Szle 1986, 79: 355-359.

11. Ember E és Szabados P: A myoarthropathia pszichoszomatikus szemlélete. Fogorv Szle 1985, 78: 234-238.

12. Ember E, VÁgó P, Bagi I, Ecsédi D, Pusztal J: A temporomandibuláris diszfunkció epidemiológiai vizsgálatának újabb vonatkozásai magyarországi populációban. Fogorv Szle 1987, 80 139-144.

13. FEJÉRDY P: A gerosztomatológia népegészségügyi vonatkozásai. In: Gerosztomatológia (szerk.: Fejérdy P, Nagy G, Orosz M), Semmelweis Kiadó, Budapest, 2007, 1-224.

14. Fejérdy P, Tollas Ö L, Fejérdy L, Borbély J, Hermann P: Fix fogmúvek jellemzőinek alakulása országos felmérések alapján. Fogorv Szle 2007, 100: 279-288.

15. Fejérdy $P$, Borbély J, Schmidt J, Jáhn M, Hermann P: Részleges lemezes fogpótlások jellemzői és hatásuk a maradékfogazatra két szűrővizsgálat összehasonlított eredményei alapján. Fogorv Szle 2008, 101: 3-11.

16. Gábris K, Márton S, Madléna M: Prevalence of malocclusion in Hungarian adolescents. European J Orthod 2006, 28: 467-470.

17. Greene CS: The etiology of temporomandibular disorders: Implication for treatment. J Orofac Pain 2001, 15: 93-105.

18. Heinrich R, Künzel W, Vágó P, Orschel H, Guckler A: Egy magyar nagyváros (Győr) időskorú lakosságának protetikai státusza szájnyálkahártya és állkapocsízületi kezelési szükséglete (II.). Fogorv Szle 1995, 88: 187-193.

19. HiRsch C, John MT, Drangsholt MT Mancl LA: Relationship between overbite/overjet and clicking or crepitus of the temporomandibular joint. J Orofac Pain 2005, 19: 218-225.

20. Hermann P, Gera I, Fejérdy P, Madléna M: Periodontal health of an adult population in Hungary: findings of a national survey. J Clin Periodontol 2009, 36: 449-457.

21. Jáhn M, Schmidt J, Fejérdy L, Tollas Ö L, Fejérdy P, Madléna M Szájnyálkahártya elváltozások előfordulási gyakorisága Magyarországon. Fogorv Szle 2007, 100: 59-63.

22. John MT, HiRsch C, Drangsholt MT, Mancl LA, Setz JM: Overbite and overjet are not related to self-report of temporomandibular disorder symptomes. J Dent Res 2002, 81: 164-169.

23. Lieberman MA, Gazit E, Fuchs C, Lilos P: Mandibular dysfunction in 10-18 year old schoolchildren as related to morphological malocclusion. J Am Dent Assoc 1985, 124: 115-121.

24. LIST T, DworkIN SF: Comparing TMD diagnosis and clinical findings at Swedish and US TMD centers using research diagnostic criteria for temporomandibular disorders. J Orofac Pain 1996, 10: 240-253.
25. LOWE AA: Correlations between orofacial muscle activity and craniofacial morphology in sample of control and anterior openbite subjects. Am J Orthod 1980, 78: 89-98.

26. LUTHER F: TMD and occlusion part II. Damned if we don't? Functional occlusal problems: TMD epidemiology in a wider context. Online article: Brit dent J 2007; 202: E3 DOI 10.1038/bdj.2006.123

27. Madléna M, Hermann $P$, Jáhn M, Fejérdy $P$ : Caries experience of Hungarian adult $s$ before joining to the European Union. Caries Res 2005, 39: 288-288.

28. Madléna M, Hermann P, Tollas Ö, Gerle J, Fejérdy P: Felnőtt korúak táplálkozási, szájhigiénés és fogorvoshoz járási szokásai kérdőíves felmérés alapján. Fogorv Szle 2007, 100: 91-97.

29. Madléna M, Hermann P, Jáhn M, Fejérdy P: Caries prevalence and tooth loss in Hungarian adult population: results of a national survey. BMC Public Health 2008, 8: 364-371.

30. Mohlin B, Axelsson S, Paulin G, Bondemark L, Brattström V, Hansen K, Holm AK: TMD in relation to malocclusion and orthodontic treatment. Angle Orthod 2007, 77: 542-548.

31. Mundt T Mack F, Schwahn C, Bernhardt O, Kocher $T$, John U, BIFFAR R: Gender differences in associations between occlusal support and signs of temporomandibular disorders: results of the population based study of health in Pomerania (SHIP). Int J Prosthodont 2005, 18: 232-239.

32. Pergamallan A, Rudy TE, Zakı HS, Greco CM: The association between wear facets and severity of facial pain in patients with temporomandibular disorder. J Prosthet Dent 2003, 90: 194-200.

33. Pullinger AG, Seligman DA: Overbite and overjet characteristics of refined diagnostic groups of temporomandibular disorder patients. Am J Orthod Dentofacial Orthop 1991, 100: 401-4015.

34. Selaimen CMP, Jeronymo JCM, Brilhante DP, Lima EM, Grossi PK, GROSsI ML: Occlusal risk factors for tempormandibular disorders. Angle Orthod 2007, 77: 471-477.

35. Slade GD, Diatchenko L, Ohrbach R, Maixner W: Orthodontic treatment, genetic factors, and risk of temporomandibular disorder. Seminars in Orthodontics 2008, 14: 146-156.

36. SzentPÉtery A, FazekAs A, Rudas K: A temporomandibuláris fájdalom - diszfunkciós szindróma epidemiológiai vizsgálata fogorvostanhallgatókon. Fogorv Szle 1986, 79: 193-197.

37. Szilágy A, Keszthelyı G, Nagy G, Cseh A, Madléna M: A Turner szindróma stomatológiai vonatkozásai II. Orthodontiai rendellenességek és a temporomandibuláris ízület néhány jellemzője, Fogorv Szle 1997, 90: 235-240.

38. Tollas ÖL, Somogy E, Madléna M, FeJérdy P: A disztálisan szabadvégü rögzített fogpótlások néhány jellemzője két, reprezentatív szürővizsgálat alapján. Fogorv Szle 2008, 101: 29-32.

39. ÚJPÁL M, BOGDÁN S, FülÖP E, BARABÁS J: Rheumatoid arthritis következtében kialakult temporomandibuláris ízületi ankylosis ritka esete. Fogorv Szle 2007, 100: 23-26.

40. VÁGó P: Az állkapocsízületi diszfunkció kóroktanának vizsgálata I. Keresztmetszeti vizsgálat. Fogorv Szle 1989a, 82: 203-206.

41. VÁGó P: Az állkapocsízületi diszfunkció kóroktanának vizsgálata II. Statisztikai módszer. Fogorv Szle 1989b, 82: 237-241.

42. VÁGó P: Az állkapocsízületi diszfunkció kóroktanának vizsgálata III. Eredmények elemzése. Fogorv Szle 1989c, 82: 269-272.

43. WHO: Oral Health Surveys: Basic Methods 4th edition. Geneva, 1997. 


\author{
Madléna M, Fejérdy P, ifJ. KaÁn M, Hermann P
}

Frequency of signs and symptoms of temporomandibular joint disorders, vertical orthodontic anomalies and their relationships based on screening of a large population

Altogether 4606 volunteers (2923 vomen, 1683 men) participated in the representative national epidemiological study to screen the alterations of temporomandibular joint (TMJ). The characteristic clinical signs and subjective complaints according to TMJ were evaluated by the medical history and physical examination. Regarding the orthodontic anomalies the vertical abnormalities (deep bite and open bite) were clinically registrated. Clinical signs showing the functional problems of TMJ were found in $45.19 \%$ of the examined population, mainly in the group of 35-44 year olds. The frequency of clicking and crepitation of TMJ was significantly higher in women comparing with men $(p<0.05)$. The highest rate of clinical signs of TMJ disorders was found in the South Transdanubian Region, the lowest one in the Middle Transdanubian region, between these regions it was a significant difference regarding the frequency of deviation/deflexion $(p<0.05)$. From the vertical abnormalities deep bite was occured most frequently in the 35-44 ys old age group. The prevalence of deep bite was higher among males than females in the whole examined population, but the difference was not statistically significant. Significant relationship was detected between deep bite and TMJ pain, deep bite and noises in the joint in the majority of the population. The most frequent anomaly in the Southern-Transdanubian Region was deep bite, while the open bite was occured most frequently in south middle part of Hungary. Conclusion: the Hungarian population needs well organized specific programs to improve the oral health including TMJ and orthodontic relations.

Keywords: epidemiology, temporomandibular joint, deep bite, open bite 